Egyptian Poultry Science Journal

http://www.epsj.journals.ekb.eg/

ISSN: 1110-5623 (Print) - 2090-0570 (Online)

\title{
EVALUATION OF GROWTH, REPRODUCTIVE PERFORMANCE AND ECONOMIC BENEFITS OF RABBITS FED DIETS SUPPLEMENTED WITH TURMERIC (CURCUMA LONGA) POWDER
}

\author{
E.O. Okanlawon'; K.O. Bello²; O.S. Akinola'; O.O.Oluwatosin ${ }^{3}$; \\ O.T. Irekhore ${ }^{3}$ and R.O. Ademolue ${ }^{1}$. \\ ${ }^{1}$ Dep. of Anim. Prod. and Health; ${ }^{2}$ Inst. of Food Sec., Envir. Reso. and Agric. Res.; \\ ${ }^{3}$ Dep. of Anim. Nut.,Fed. Uni. of Agric. Abeokuta
}

Corresponding Author: E.O. Okanlawon ${ }^{1}$ email:edenokanlawon@ gmail.com

Received: 28/06/2020 Accepted: $21 / 09 / 2020$

\begin{abstract}
Sixty four (7-8 weeks old) crossbred male and female rabbits weighing between 700 and $800 \mathrm{~g}$ were used to determine the effect of inclusion of Turmeric (Curcuma longa) powder on growth, economic benefits and reproductive performance of rabbits. The rabbits on sex basis were randomly allotted to diets containing four levels $(0 \%, 0.5 \%, 1.0 \%$ and $1.5 \%$ ) of turmeric powder as a supplement in a $2 \times 4$ factorial arrangement. Data were collected on growth performance and economic benefits. Reproductive, At 20 weeks old, 24 rabbits comprising of 8 bucks and 16 does along dietary treatment were used for reproductive performance evaluation in mating ratio of 1:2 per treatment. Data were collected on gestation length, litter size, birth weight and weaning weight. Data collected were analyzed using ANOVA. Highest $(\mathrm{p}<0.05)$ weight gain $(700.71 \mathrm{~g})$ was obtained with rabbits fed diet containing $1.0 \%$ turmeric supplement. Daily feed intake was $(\mathrm{p}<0.05)$ highest $(113.76 \mathrm{~g})$ within rabbits on $1.5 \%$ turmeric supplement while the least $(99.48 \mathrm{~g})$ was recorded with rabbits fed diets containing $0.5 \%$ inclusion. There was no significant difference $(\mathrm{P}>0.05)$ on feed conversion ratio of the rabbits.. Litter size was $(\mathrm{p}<0.05)$ highest $(5.25)$ with rabbit fed $1.0 \%$ turmeric inclusion while least (3.00) was recorded with $1.5 \%$ turmeric inclusion. Litter weight at kindling was also significantly $(\mathrm{p}<0.05)$ highest $(147.25 \mathrm{~g})$ with rabbits fed $1.0 \%$ turmeric inclusion. No significant $(\mathrm{p}>0.05)$ difference was recorded on gestation length, litter size at weaning and weaning weight. The study concluded that turmeric inclusion had no detrimental effect of growth performance of rabbits. However, 1.0\% supplement appeared as economic inclusion level for weight gain, efficient feed utilization, optimum profit, economic benefit, litter size and litter weight at kindling in rabbit production enterprise.
\end{abstract}

Key words: rabbit, turmeric, growth, economic, reproductive performance 


\section{INTRODUCTION}

Rabbit (Oryctolagus cunniculus) has been identified as one of the animals that can be reared successfullly at family level (FAO, 1996), because of is favorable biological characteristics as most monogastric species, short gestation interval and a high prolificacy (Beaumont et al., 2002). Rabbit is also reputable in the field of medicine research and biotechnological application (Chantry-Darmon et al., 2003) and can therefore be categorized as multi-purpose animal for research and human uses. Rabbit requires cheap sources of feed, easily constructed housing and do not compete with humans for cereals as strongly as chickens or pigs for instance (Petrescu et al., 2013). Rabbit meat has amazing protein (about 22\%), low fat (4\%) and cholesterol (5\%) and therefore has health promoting qualities (Aduku and Olukosi, 1990; Gondret and Bonneau, 1998; Oladunjoye et al., 2006; Nistor et al., 2013). Nistor et al., (2013) reported that rabbit meat is better-off in calcium $(21.4 \mathrm{mg} / 100 \mathrm{~g})$ and phosphorus $(347 \mathrm{mg} / 100 \mathrm{~g})$ than other types of meat and lower in fat $(9.2 \mathrm{~g} / 100 \mathrm{~g})$ and cholesterol $(56.4 \mathrm{mg} / 100 \mathrm{~g})$. Its meat is appreciated for its organoleptic properties in particular through its high crude protein/ energy ratio, high essential fatty acids content and low cholesterol rate (Gondret and Bonneau, 1998). Rabbit could be explored as cheaper and quality meat-type animal for the fast growing human populate in the developing counties in particular if adequately researched with natural plant materials as efficient and reliable feed additive for better performance, food and nutrition security.

Rabbits have extraordinary reproductive potential because of their rapid growth rate, short gestation period and capability to breed immediately after parturition (Aduku and Olukosi, 1990). This amazing reproductive efficiency is rare in order animals. Growth performance, carcass yield and organ weights of rabbits are influenced by dietary crude protein level (Obinne, 2002). Studies on the reproductive system showed that feeding is one of the major restricting factors in achieving all-out performance in rabbit breeding (Iheukwumere and Okoli, 2002). Asuquo (1993) observed that poor nutrition delayed sexual maturity in rabbits resulting in low marginal financial returns on investment to the farmer. Lebas (1983) and Effiong and Wogar (2007) advocated increased feeding and nutrient levels for breeding rabbits as a means of adequate maintenance of pregnancy, increasing the litter size, and subsequent milk let-down by the does.

Meanwhile the economic and nutritional demands of the fast growing human population necessitate increase in animal production using modern production system. Under such production system, antimicrobial feed additives such as antibiotics are frequently used to suppress or eradicate harmful microorganisms and to improve growth and feed efficiency. However, one major aspect of food production and safety today is the reduction in the use of antibiotics and other medicinal products in livestock production largely due to fears over bacterial resistance and possible transmission of these antibiotic residues into the human food chain. In the last two decades, considerable research has been carried out on exploring the beneficial effects from the growth promoters and finding suitable alternative to antibiotics (Berge,2017). Research is still on going to find out more of such natural products to enhance the performance of rabbit as well as for an economically feasible and viable alternatives to the antibiotic growth promoters (AGPs). Such examples of natural growth promoters are prebiotics, probiotics and phytobiotics.

Phytobiotics are relatively novel class of feed additives and have gained huge attention in the poultry industry in recent years. Phytobiotics are plant derived 
products (leaves, roots, flowers, whole plants or extracts) which when added to the Livestock feeds helps to boost performance (Grashhorn, 2010). Utilization of phytobiotics as natural growth promoters (NGPs) has been acknowledged as effective alternative to antibiotics (Panda et al., 2009). Phytobiotics as NGPs are highly developed as feed additives, improve immunity, growth performance and effective in improving the health of the digestive tract (Panda et al., 2009; Berge, 2017). Considerable attention has been focused on the use of herbal medicines and their derivatives in healing diverse ailments related to oxidative stress (Lee and Pack, 2003). Phytobiotics are also known to be an effective antimicrobial and anticoccidia (Panda et al., 2006). Feeding diets containing phytobiotics help prevent the growth and colonization of enteropathogenic microbes in the digestive tract and consequently contributing to the balance of gut microflora and ecology (Harris et al., 2001). Example of phytobiotics includes garlic, turmeric, ginger etc.

Turmeric (Curcuma longa), is a perennial herb and a member of the ginger family, Zingaberaceae and a very important herb in Indian Ayurvedic medicine. For centuries in the Indian traditional system of medicine, turmeric has been used as a spice and a natural food colour. Curcumin is the active ingredient in turmeric and it contains three components, namely curcumin, demethoxycurcumin and methoxycurcumin, all which are referred to the curcuminoids (Aggarwal et al., 2003). Curcumin gives turmeric with its characteristics yellow colour and is recognized as being responsible for most of its therapeutic effects, such as antibacterial, antifungal, anti-protozoa, antiviral, antioxidant, antiinflammatory, and hypo-cholesterolemic, activities (Chattopadhyay et al.,2004).

Turmeric has a wide array of health benefits at low cost and no adverse effects (Soni et al., 1997) in livestock production. Due to some vitamins and minerals that turmeric contains and ban of antibiotics, it has also been used as dietary supplementation on voluntary feed intake, nutrient digestibility and growth performance both in rabbit and poultry (Osawa et al., 1995). However, there is dearth information on holistic effect of turmeric as feed additive on sex, growth, economic benefitsand reproductive performance of rabbit and this therefore necessitates the present study.

\section{MATERIALS AND METHODS}

The study was conducted at the Rabbitary unit of Federal College of Agriculture Farm, Institute of Agriculture Research and Training (IAR\&T) Ibadan, Oyo State, Nigeria. The location lies within the rain forest vegetation zone of south west Nigeria with mean annual rainfall of $1420.06 \mathrm{~mm}$, a temperature of $31.2^{\circ} \mathrm{C}$ and a relative humidity of $72 \%$. It is located about 836 feet above sea level, on latitude $7^{0} 25^{\prime} 19,7^{\prime}{ }^{\prime} \mathrm{N}$ and longitude $3^{0} 51^{\prime} 30.5^{\prime}$ 'E. Turmeric was purchased from open market within Ibadan metropolis and the turmeric rhizome was cut into slices in order to increase the surface area. The slice were boiled for 30-45 minutes in water bath at $60^{\circ} \mathrm{C}$ to soften the turmeric and make grinding easy and also enhance its colour and flavour. Thereafter the boiled turmeric was air dried for 10 days and milled into fine powdery according to the method described by Jayaprakasha et al. (2005) and stored in air tight container until use.

A total of 64 (8 weeks old) comprising of 32 male (buck) and 32 female (doe) with an average weight of $700 \mathrm{~g}$ weaned rabbits were used for the study. The animals were purchased from a reputable farm. They were weighed and acclimatize for two weeks before they were allotted into 4 treatments in a $2 \times 4$ factorial arrangement comprising of sex (male and female) of rabbits and four levels $(0,0.5,1.0,1.5 \%)$ of turmeric inclusion effect on sex, growth, economic benefitsand reproductive performance. Each treatment had 8 replicates of 2 rabbits each. Before stocking, the pen (house) was cleaned thoroughly with detergent and water. These animals were fed with a 
commercial grower diet containing $16 \%$ crude protein (CP) and $2450 \mathrm{kcal} / \mathrm{kg}$ metabolizable energy (ME). Feed and water were supplied ad libitum daily. All other routine management practices were observed. After the growth performance study which lasted for 10 weeks, a total of 24 (16 does and 8 bucks) rabbits were crossed at 20 weeks of age. Natural matting was adopted in which the does in each treatment were crossed with buck within the same treatment. A buck was used to service 2 does at mating ratio 1:2. Each cross served as a replicate. Palpation of the does was done on the 14 day after mating through gentle compression of the walls of the abdomen towards the middle line with the right hand under the abdomen and in front of the pelvis after properly restraining the rabbit with the left hand. The reproductive study lasted for 10 weeks and the kit were weaned when they were 6 weeks of age.

Rabbits were weighed individually at the beginning of the study and subsequently on weekly basis. Weight gain was determined by calculating the difference between the final body weight and the initial body weight. Feed intake was determined through deduction of leftover feed from supply. Cost per kilogram feed ( $)$ and total feed intake per animal (kg/rabbit) was calculated using prevailing market price. Data were also collected on gestation length, litter size, litter weight at birth, litter size at weaning and weaning weight.

All data collected were analysed using ANOVA as contained in SAS (2002). Significant means were separated using Duncan Multiple Range Test as contained in SAS (2002).

\section{RESULTS AND DISCUSSION}

Table 1 shows effect of sex on growth performance of male and female rabbits fed diets supplemented with turmeric (Curcuma longa) powder. There was no significant difference $(\mathrm{P}>0.05)$ on weight gain of the buck $(662.34 \mathrm{~g})$ and the doe $(607.48 \mathrm{~g})$. This result was in line with the findings of Iyeghe-Erakpotobor (2009) who reported similarity in weight gain between male and female of rabbits fed groundnut forage meal. The finding of Jaya et al. (2009) who reported no significance on effect of sex on body weight of rabbits reared under different system gave credence to the result obtained in this current study. The result obtain for body weight gain was in accordance with that of Ekpo et al. (2008) who reported that sex had no significance effects on body weight gain of rabbits fed unpeeled and peeled cassava tuber meal and cassava peel meal. There was no significant difference $(\mathrm{P}$ $>0.05)$ on feed intake of the doe (108.32 $\mathrm{g}$ ) and buck (105.99 g). Result of feed intake obtained in this study was in contrast with the report of Lazzaroni et al. (2009) who reported higher feed intake in female rabbits than male on different rearing systems for fattening rabbits. Also no significant difference $(\mathrm{P}>0.05)$ on feed conversion ratio of doe and buck fed diets supplemented with turmeric powder. The finding of Bello et al. (2015) who reported that sex had no effect on body weight gain, feed intake and feed conversion ratio rabbits raised different frequency of litter change.

Table 2 shows main effects of turmeric powder inclusion on growth performance of rabbits. Significant $(\mathrm{P} \leq 0.05)$ differences were obtained on the total weight gain and daily feed intake of rabbits fed diets supplemented with varying levels of turmeric powder. Highest $(\mathrm{P} \leq 0.05)$ weight gain $(700.71 \mathrm{~g})$ was obtained with rabbits fed diet containing $1.0 \%$ turmeric inclusion while rabbits on $0.5 \%$ turmeric inclusion had the least weight gain (501.13g). Effect of turmeric on growth performance of rabbits had significant increase on weight gain at $1.0 \%$ inclusion, this may be due to phytobiotic level of Turmeric (Curcuma longa) in the body tissue of rabbit. This result was similar with that of Salih et al. (2013) who reported that inclusion of turmeric at $7 \mathrm{~g} / \mathrm{kg}$ diet significantly influenced body weight gain of broiler chicken, findings was also in consonant with the results of Osawa et al. (1995) who 
reported that increased weight gain of bird is due to the phytobiotic activity of turmeric.

Moreover, Holder et al. (1978) found a slightly lower weight gain across treatment group of broiler rabbits fed graded levels of turmeric and attributed the variation to the higher concentration of Curcuma longa in feed mixture, which might cause poor feed absorption from the intestine. Feed intake was significantly $(\mathrm{P} \leq 0.05)$ highest $(113.76 \mathrm{~g})$ in rabbits on $1.5 \%$ turmeric inclusion while the least $(99.48 \mathrm{~g})$ was recorded with rabbits fed diets containing $0.5 \%$ inclusion. The decrease in feed intake of rabbits at $0.5 \%$ turmeric inclusion was contrary to the opinion of Basavaraj et al. (2010) who stated that increase in turmeric levels across broiler rabbit groups lead to a fall in the daily feed intake. Results of the main effect of turmeric powder in this study were also contrary with findings made by Wuthi-udomler et al. (2000), Emadi and Kermanshahi (2007) and Durrani et al. (2006) in chicks. They reported that at $0.5 \%$ level turmeric significantly decreased feed intake in chick. This probably suggest inclusion rate of turmeric according to physiological stage of production of any species of livestock.

There was no significant difference $(\mathrm{P}>$ 0.05 ) on feed conversion ratio of rabbit fed diets containing varying levels of turmeric inclusion. Highest (poorest) feed conversion was recorded with rabbit on $0.5 \%$ turmeric inclusion among the 4 dietary treatments. This result in this study was similar with that of Salih et al. (2013) who reported that inclusion of turmeric at $7 \mathrm{~g} / \mathrm{kg}$ had better FCR when compare to other treatment group in broiler and this was in variance with the findings of Emadi and Kermanshashi (2007) and Durrani et al. (2006) who noted that $0.5 \%$ level elicited better feed conversion ratio in chicks than 0.25 and $1.0 \%$ level of turmeric in diet of chicks. The variation could be due to the type of physiological state and nutrient requirement of the animal, while chicks require $20-23 \%$ of crude protein and $3.5-4.0 \%$ crude fibre at this physiological stage. That experimental rabbits in this study were 8 weeks old weaned and they required $16 \%$ crude protein and $7 \%$ crude fibre therefore could be able to tolerate more turmeric in their body system than chicks that have relatively smaller body size.

Table 3 shows interaction between sex and inclusion level of turmeric powder on growth performance of rabbits. Highest ( $\mathrm{P} \leq$ $0.05)$ total weight gain $(785.13 \mathrm{~g})$ was obtained with buck fed diet that contained $1.0 \%$ turmeric inclusion while doe fed with diet containing $0.5 \%$ turmeric inclusion had least $(442.25 \mathrm{~g})$. The significant increase in body weight at $1.0 \%$ of the buck may be due to optimum antioxidant capability of turmeric (Curcuma longa) that provides fortress for preventing disease pathogen from invading and confronting other challenges for better feed digestion, absorption and utilisation (Berge, 2017) which stimulate protein and body tissue of rabbit. This was in agreement with findings of Osawa et al. (1995) who reported that increased weight gain is due to the antioxidant activity of turmeric. The result of weight gain was in agreement with report of Ramirez et al. (1999) on oral administration of turmeric in rabbit and the opinion of (Panda et al., 2009) on utilization of phytobiotics as natural growth promoters. Turmeric inclusion had no significant $(\mathrm{P}>$ 0.05) effects on feed conversion ratio. Though best feed conversion was recorded at $1.0 \%$ inclusion of the buck among the 4 dietary treatments. This result is similar with that of Salih et al. (2013) who reported that inclusion of turmeric at $7 \mathrm{~g} / \mathrm{kg}$ diet significantly affect body weight gain of broiler when compared to other treatment groups but was at variance with the findings of Emadi and Kermanshashi (2007) and Durrani et al. (2006) who noted that $0.5 \%$ level elicited better feed conversion ratio than 0.25 and $1.0 \%$ level of turmeric diet of chicks.

There was significant variation $(\mathrm{P} \leq 0.05)$ in daily feed intake. Feed intake was highest 
(116.13g) with doe fed diet containing $1.5 \%$ turmeric inclusion and least (96.62g) among does fed diet with $0.5 \%$ turmeric inclusion. Buck and doe on $0.5 \%$ turmeric level of inclusion had least daily feed intake. Similar observations were made by Emadi and Kermanshahi (2007) and Durrani et al. (2006) with chicks. They reported that at $0.5 \%$ level, turmeric significantly reduced feed consumption in chick. It was also reported by Omage et al. (2007) that there was significant difference in feed intake of rabbits fed varying level of ginger. In this study $1.0 \%$ turmeric inclusion level probably suggest optimum inclusion level for rabbit production.

Table 4 show effect of sex on economic benefit of rabbit fed diet supplemented with turmeric powder. No significant difference $(\mathrm{P}>0.05)$ was recorded on cost of feed per $25 \mathrm{~kg}$ diet and as well as cost per $\mathrm{kg}$ diets. There was no significant difference $(\mathrm{P}>$ $0.05)$ of turmeric supplementation on cost per daily feed intake of male and female rabbits. Similarly, turmeric supplementation had no significant consequence $(\mathrm{P}>0.05)$ on cost of feed per $\mathrm{kg}$ body weight gain of male and female rabbits. The result was in line with the finding of Iyeghe-Erakpotobor et al. (2015) who reported the effect of forage type and level, palm oil supplementation and sex on performance of weaner rabbits.

Table 5 shows main effects of turmeric powder inclusion on economic benefit of rabbits. There was significant difference $(\mathrm{P} \leq$ $0.05)$ on cost of feed per $25 \mathrm{~kg}$ with turmeric inclusion. Feed supplemented with $1.5 \%$ turmeric inclusion had the highest cost ( $\$ 2363.50 / 25 \mathrm{~kg}$ ) while the least cost (\$2100) was obtained at $0 \%$ turmeric inclusion. Also there was significant difference $(\mathrm{P} \leq 0.05)$ on cost per kilogram diet which was highest at $1.5 \%$ ( $\$ 94.54 / \mathrm{kg}$ ) and lowest at $0.0 \%$ ( $\$ 84.00 / \mathrm{kg}$ ). Highest (P $\leq 0.05)$ cost per daily feed intake ( $\$ 10.75$ ) was recorded at $1.5 \%$ inclusion and least at $0.5 \%$ ( $\$ 8.88$ ). Cost of feed per $\mathrm{kg}$ body weight gain also varied $(\mathrm{P} \leq 0.05)$ with varying level of turmeric inclusion.
However, highest cost of feed per kg body weight gain ( $\$ 134.74$ ) was recorded at $1.5 \%$ turmeric inclusion and lowest $(\$ 101.25)$ at $0.5 \%$. The result obtained on cost per $25 \mathrm{~kg}$ diet, cost per $\mathrm{kg}$ diet, cost per daily feed intake and cost per kg body weight gain was in agreement with the report of Durrani et al. (2006) who noted that $0.5 \%$ inclusion level had highly favourable cost of feed on chick than other treatments. This was not unexpected as cost of feed increased with increased turmeric level. However, 1.0\% turmeric inclusion could be assumed to be the best since the inclusion on feed intake was similar with control diet $(0.0 \%)$.

Table 6 shows interaction between sex and inclusion level of turmeric powder on economic benefits of rabbits. There was significant variance $(\mathrm{P} \leq 0.05)$ on cost of feed per $25 \mathrm{~kg}$. Turmeric inclusion at $1.5 \%$ was highest ( $\$ 2363.50$ ) in both buck and doe while the least ( $\$ 2100$ ) was at $0 \%$ in both buck and doe. Also, there was significant difference $(\mathrm{P} \leq 0.05)$ on cost per $\mathrm{kg}$ diet. There was significant difference $(\mathrm{P}$ $\leq 0.05$ ) on cost per daily feed intake. Highest similar cost per daily feed intake ( $\$ 10.98$ ) was obtained among doe fed supplemented turmeric at $1.5 \%$ with turmeric inclusion and buck ( $\$ 10.53$ ) but least cost per daily feed intake ( $\$ 8.79$ ) was recorded with doe on $0.5 \%$ turmeric inclusion. There was nonsignificant difference $(\mathrm{P}>0.05)$ on cost of feed per kg body weight gain, even though highest cost of feed per $\mathrm{kg}$ body weight gain was recorded with doe on $1.5 \%$ turmeric inclusion ( $\$ 137.19)$ and least $(\$ 83.68 \mathrm{~g})$ with doe on $0.5 \%$ inclusion. The result obtained for both buck and doe on cost per $25 \mathrm{~kg}$ diet, cost per $\mathrm{kg}$ diet, cost per daily feed intake and cost of fed per $\mathrm{kg}$ body weight was in agreement with that of Durrani et al. (2006) who noted that $0.5 \%$ inclusion level had highly favourable cost of feed than other treatment in chicks. The variation could be due to the physiology of animals.

Table 7 shows the effects of turmeric powder inclusion on reproductive 
performance of female rabbits. There was no significant difference $(\mathrm{P}>0.05)$ on gestation length. Shortest gestation period (31.5 day) was recorded with rabbits fed $1.5 \%$. Similarly the gestation length recorded in this study still fall within the normal range of 29-35 days reported by Lebas (1983). Highest $(\mathrm{P} \leq 0.05)$ litter size (5.25) was recorded with rabbit fed diet supplement with $1.0 \%$ turmeric powder. This is consistent with the report of Iyabode et al. (2014) on reproductive response of rabbit does to diets containing varying levels of (Moringa oleifera) leaf meal. Highest significant $(\mathrm{P} \leq 0.05)$ litter weight $(147.25 \mathrm{~g})$ was recorded at $1.0 \%$ which is in agreement with the report of Iyabode et al. (2014) on reproductive response of rabbit does to diets containing varying levels of (Moringa oleifera) leaf meal, Aduku and Olukosi (1990), Gupta et al. (1999) and Okereke et al. (2009) who investigated the factors influencing pre- weaning body weight of rabbits and effect of feeding graded levels of soaked acacia pods in rabbits feeding but contradicted that of Odeyinka et al. (2008) who recorded no significant effects on birth weight of litters from does fed varying levels of Moringa oleifera leaf meal replacing Centrosema at $30 \%$ inclusion level.

Result in this study was in agreement with (Poigner et al., 2000) who reported that generally individual birth weight decreases with increase in litter size. Highest litter size and weight at weaning ( $\mathrm{g}$ ) was recorded at $0.5 \%$. The variations in the litter size in addition to weight at weaning could be associated with the lactation status of the dam, good mothering ability of the dam and the number of suckling kits. Result in this study was in agreement with (Poigner et al., 2000) who reported that generally individual birth weight decreases with increase in litter size. Kits of lager litters generally show a lower weight at weaning than the corresponding weight for kits of smaller litters. This is because their weight gain depends on milk intake. Doe milk production is positively related to litter size at weaning as reported by (McNitt and Lukefahr, 1989; Ayyat et al., 1995). Nevertheless, kits of larger litters consume less milk than those of smaller litters.

\section{CONCLUSION}

From the results obtained from this study, it could be concluded that sex and turmeric inclusion had no detrimental effect on growth performance of rabbits. However, $1.0 \%$ inclusion could be assumed as economic inclusion level for weight gain, efficient feed utilization, least cost diet formulation, optimum profit, litter size and litter weight at kindling in rabbit production enterprise. 
Table (1): Effects of sex on growth performance of rabbit fed diet supplemented with turmeric powder.

\begin{tabular}{|l|c|c|}
\hline \multirow{2}{*}{ Parameter } & \multicolumn{2}{|c|}{ Effect of sex on performance } \\
\cline { 2 - 3 } & Female & Male \\
\hline Initial weight, $(\mathrm{g})$. & $701.31 \pm 17.77$ & $696.53 \pm 14.67$ \\
Total weight gain, $(\mathrm{g})$. & $607.48 \pm 58.49$ & $662.34 \pm 29.85$ \\
ADWG, $(\mathrm{g} / \mathrm{r} / \mathrm{d})$. & $9.19 \pm 0.70$ & $9.46 \pm 0.43$ \\
ADFI, $(\mathrm{g} / \mathrm{r} / \mathrm{d})$. & $108.32 \pm 2.22$ & $105.99 \pm 1.49$ \\
FCR, $(\mathrm{g}$ feed/g gain). & $12.79 \pm 0.89$ & $11.51 \pm 0.49$ \\
\hline
\end{tabular}

ADWG: Average daily weight gain.

ADFI: Average daily feed intake.

FCR: Feed conversion ratio.

g/ r/ d: Gram/ rabbit/ day.

Table (2): Main effects of turmeric powder inclusion on growth performance of rabbits.

\begin{tabular}{|l|c|c|c|c|}
\hline \multirow{2}{*}{ Parameters } & \multicolumn{3}{|c|}{ Inclusion level of turmeric (\%) } \\
\cline { 2 - 5 } & $\mathbf{0 . 0}$ & $\mathbf{0 . 5}$ & $\mathbf{1 . 0}$ & $\mathbf{1 . 5}$ \\
\hline Initial weight, (g). & $689.50 \pm 20.28$ & $698.81 \pm 27.08$ & $704.38 \pm 21.49$ & $703.00 \pm 25.55$ \\
Total weight gain, (g). & $663.31 \pm 64.69^{\mathrm{ab}}$ & $501.13 \pm 70.92^{\mathrm{b}}$ & $700.71 \pm 41.75^{\mathrm{a}}$ & $674.50 \pm 66.63^{\mathrm{ab}}$ \\
ADWG, (g/ r/ d). & $9.48 \pm 0.92$ & $8.04 \pm 0.57$ & $10.01 \pm 0.59$ & $9.64 \pm 0.95$ \\
ADFI, (g/ r/ d). & $106.45 \pm 1.53^{\mathrm{b}}$ & $99.48 \pm 2.26^{\mathrm{c}}$ & $108.91 \pm 2.34^{\mathrm{ab}}$ & $113.76 \pm 1.82^{\mathrm{a}}$ \\
FCR, (g feed/ g gain). & $11.99 \pm 1.18$ & $12.85 \pm 0.82$ & $11.19 \pm 0.81$ & $12.58 \pm 1.19$ \\
\hline
\end{tabular}

a, b, c and d: means in the same row by factor with different superscripts differ significantly $(\mathrm{P} \leq 0.05)$.

ADWG: Average daily weight gain.

ADFI: Average daily feed intake.

FCR: Feed conversion ratio.

g/ r/ d: Gram/ rabbit/ day. 
Table (3): Interaction between sex and inclusion level of turmeric powder on growth performance of rabbits.

\begin{tabular}{|c|c|c|c|c|c|c|c|c|}
\hline \multirow{2}{*}{ Parameters } & \multicolumn{4}{|c|}{$\begin{array}{c}\text { Doe } \\
\text { Inclusion level of turmeric Powder (\%) }\end{array}$} & \multicolumn{4}{|c|}{$\begin{array}{c}\text { Buck } \\
\text { Inclusion level of turmeric Powder (\%) }\end{array}$} \\
\hline & 0.0 & 0.5 & 1.0 & 1.5 & 0.0 & 0.5 & 1.0 & 1.5 \\
\hline $\begin{array}{l}\text { Initial body } \\
\text { weight, (g). }\end{array}$ & $\begin{array}{c}684.50 \pm \\
43.25\end{array}$ & $\begin{array}{c}707.25 \pm \\
26.76\end{array}$ & $\begin{array}{c}711.38 \pm \\
33.84\end{array}$ & $\begin{array}{c}702.13 \pm \\
49.44\end{array}$ & $\begin{array}{c}694.50 \pm \\
5.67\end{array}$ & $\begin{array}{c}690.38 \pm \\
51.57\end{array}$ & $\begin{array}{c}697.38 \pm \\
31.28\end{array}$ & $\begin{array}{c}703.88 \pm \\
24.51\end{array}$ \\
\hline Total & $652.13 \pm$ & $442.25 \pm$ & $616.29 \pm$ & $719.25 \pm$ & $674.50 \pm$ & $560.00 \pm$ & $785.13 \pm$ & $629.75 \pm$ \\
\hline weight gain, & $132.22^{\mathrm{ab}}$ & $135.06^{\mathrm{b}}$ & $40.58^{\mathrm{ab}}$ & $130.79^{\mathrm{ab}}$ & $44.36^{\mathrm{ab}}$ & $54.05^{\mathrm{ab}}$ & $41.67^{\mathrm{a}}$ & $47.69^{a b}$ \\
\hline ADWG, (g/ & $9.31 \pm$ & $8.09 \pm$ & $8.80 \pm$ & $10.28 \pm$ & $9.64 \pm$ & $8.00 \pm 0.77$ & $11.22 \pm$ & $8.99 \pm$ \\
\hline $\mathrm{r} / \mathrm{d})$ & 189 & 1.05 & 0.58 & 1.8 & 0.63 & & 0.5 & \\
\hline ADFI, (g/r/ & $\begin{array}{r}107.82 \pm \\
166 \mathrm{abc}\end{array}$ & $96.62 \pm$ & $112.74 \pm$ & $116.13 \pm$ & $105.15 \pm$ & $102.35 \pm$ & $105.09 \pm$ & 111.39 \\
\hline $\begin{array}{l}\text { d) } \\
\text { FCR, }\end{array}$ & $\begin{array}{c}1.66^{\mathrm{abc}} \\
12.98 \pm\end{array}$ & $\begin{array}{c}3.70^{\mathrm{d}} \\
12.59 \pm\end{array}$ & $\begin{array}{c}3.51^{\mathrm{ab}} \\
12.98 \pm\end{array}$ & $\begin{array}{c}1.69^{\mathrm{a}} \\
12.59 \pm\end{array}$ & $\begin{array}{l}3.65^{\mathrm{bc}} \\
11.01 \pm\end{array}$ & $\begin{array}{c}7.18^{\mathrm{cd}} \\
13.05 \pm\end{array}$ & $\begin{array}{l}3.11 \mathrm{~h}^{\mathrm{c}} \\
942+\end{array}$ & $+7.97^{\text {ab }}$ \\
\hline feed/ g & & 176 & 090 & 2.39 & 049 & 089 & 035 & $\begin{array}{l}1.92 \\
+0.92\end{array}$ \\
\hline
\end{tabular}

$\mathrm{a}, \mathrm{b}, \mathrm{c}, \mathrm{d}$ : Means in the same row with different superscripts differ significantly $(\mathrm{P} \leq 0.05)$.

DWG: daily weight gain.

글 DFI: daily feed intake.

g/ r/ d: Gram/ rabbit/ day.

FCR: Feed conversion ratio. 
Table (4): Effects of sex on economic benefit of rabbit fed diet Supplemented with turmeric powder.

\begin{tabular}{|c|c|c|}
\hline \multirow[b]{2}{*}{ Parameter } & \multicolumn{2}{|c|}{ Effect of sex on Performance } \\
\hline & Female & Male \\
\hline 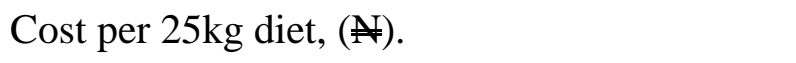 & $2248.22 \pm 25.16$ & $2248.22 \pm 25.16$ \\
\hline Cost per kg diet, $(\mathbb{N} / \mathrm{kg})$. & $89.93 \pm 1.01$ & $89.93 \pm 1.01$ \\
\hline Cost per daily feed intake, ( $)$. & $9.76 \pm 0.27$ & $9.54 \pm 0.20$ \\
\hline Cost of feed per kg body weight gain, ( $\mathrm{N} / \mathrm{kg})$. & $118.41 \pm 11.77$ & $109.75 \pm 5.19$ \\
\hline
\end{tabular}

a, b, c: Means in the same row with different superscripts differ significantly $(\mathrm{P} \leq 0.05)$.

Table (5): Main effects of Turmeric powder inclusion on economic benefit of rabbits.

\begin{tabular}{|l|c|c|c|c|}
\hline \multirow{2}{*}{ Parameters } & \multicolumn{4}{|c|}{ Inclusion level of Turmeric (\%) } \\
\cline { 2 - 5 } & $\mathbf{0 . 0}$ & $\mathbf{0 . 5}$ & $\mathbf{1 . 0}$ & $\mathbf{1 . 5}$ \\
\hline Cost per 25kg diet, (\#). & $2100.00 \pm 0.00^{\mathrm{d}}$ & $2231.75 \pm 0.00^{\mathrm{c}}$ & $2297.63 \pm 0.00^{\mathrm{b}}$ & $2363.50 \pm 0.00^{\mathrm{a}}$ \\
Cost per daily feed intake, (\#). & $8.95 \pm 0.13^{\mathrm{c}}$ & $8.88 \pm 0.20^{\mathrm{c}}$ & $10.01 \pm 0.22^{\mathrm{b}}$ & $10.75 \pm 0.17^{\mathrm{a}}$ \\
Cost of feed per kg body weight gain, ( $/ \mathrm{kg})$. & $107.65 \pm 11.28$ & $101.25 \pm 16.20$ & $112.65 \pm 9.48$ & $134.74 \pm 12.21$ \\
\hline
\end{tabular}

$\mathrm{a}, \mathrm{b}, \mathrm{c}$ : Means in the same row with different superscripts differ significantly $(\mathrm{P} \leq 0.05)$. 
Table (6): Interaction between sex and inclusion level of Turmeric powder on economic benefits of rabbits

\begin{tabular}{|c|c|c|c|c|c|c|c|c|}
\hline \multirow{2}{*}{ Parameters } & \multicolumn{4}{|c|}{$\begin{array}{c}\text { Doe } \\
\text { Inclusion level of Turmeric Powder }(\%)\end{array}$} & \multicolumn{4}{|c|}{$\begin{array}{c}\text { Buck } \\
\text { Inclusion level of Turmeric Powder (\%) }\end{array}$} \\
\hline & 0.0 & 0.5 & 1.0 & 1.5 & 0.0 & 0.5 & 1.0 & 1.5 \\
\hline Cost of $25 \mathrm{~kg}$ diet, $(\#)$. & $\begin{array}{c}2100.00 \pm \\
0.00^{\mathrm{d}}\end{array}$ & $\begin{array}{l}2231.750 \\
\pm 0.00^{\mathrm{c}}\end{array}$ & $\begin{array}{c}2297.63 \\
\pm 0.00^{\mathrm{b}}\end{array}$ & $\begin{array}{c}2363.50 \\
\pm 0.00^{\mathrm{a}}\end{array}$ & $\begin{array}{l}2100.00 \\
\pm 0.00^{\mathrm{d}}\end{array}$ & $\begin{array}{c}2231.75 \\
\pm 0.00^{\mathrm{c}}\end{array}$ & $\begin{array}{l}2297.63 \\
\pm 0.00^{\mathrm{b}}\end{array}$ & $\begin{array}{c}2363.50 \pm \\
0.00^{\mathrm{a}}\end{array}$ \\
\hline Cost of daily feed intake, ( & $\begin{array}{l}9.06 \pm \\
0.14^{\mathrm{bc}}\end{array}$ & $\begin{array}{l}8.79 \pm \\
0.33^{\mathrm{c}}\end{array}$ & $\begin{array}{c}10.36 \pm \\
0.23^{\mathrm{a}}\end{array}$ & $\begin{array}{c}10.98 \pm \\
0.16^{\mathrm{a}}\end{array}$ & $\begin{array}{l}8.83 \pm \\
0.22^{\mathrm{c}}\end{array}$ & $\begin{array}{l}9.13 \pm \\
0.19^{\mathrm{bc}}\end{array}$ & $\begin{array}{c}9.66 \pm \\
0.29^{\mathrm{b}}\end{array}$ & $\begin{array}{c}10.53 \pm \\
0.28^{\mathrm{a}}\end{array}$ \\
\hline $\begin{array}{l}\text { Cost of feed per body weight gain, } \\
(\$ / \mathrm{kg}) \text {. }\end{array}$ & $\begin{array}{c}118.33 \pm \\
22.58\end{array}$ & $\begin{array}{c}83.68 \pm \\
31.19\end{array}$ & $\begin{array}{c}134.43 \pm \\
9.54\end{array}$ & $\begin{array}{c}137.19 \pm \\
24.28\end{array}$ & $\begin{array}{l}96.975 \pm \\
2.76\end{array}$ & $\begin{array}{c}118.83 \pm \\
6.78\end{array}$ & $\begin{array}{c}90.86 \pm \\
3.5\end{array}$ & $\begin{array}{l}132.34 \\
\pm 10.13\end{array}$ \\
\hline
\end{tabular}

a, b, c, d: Means in the same row with different superscripts differ significantly $(\mathrm{P} \leq 0.05)$. 
E.O. Okanlawon1, E. O. ${ }^{1}$ et al.

Table (7): Effects of Turmeric powder inclusion on reproductive performance on female.

\begin{tabular}{|l|c|c|c|c|}
\hline \multirow{2}{*}{ Parameters } & \multicolumn{4}{|c|}{ Inclusion level of turmeric (\%) } \\
\cline { 2 - 5 } & $\mathbf{0 . 0}$ & $\mathbf{0 . 5}$ & $\mathbf{1 . 0}$ & $\mathbf{1 . 5}$ \\
\hline Gestation length, (d). & $32.00 \pm 0.91$ & $32.00 \pm 0.00$ & $32.25 \pm 0.48$ & $31.50 \pm 0.87$ \\
Litter size & $5.00 \pm 0.82^{\mathrm{a}}$ & $3.50 \pm 0.29^{\mathrm{ab}}$ & $5.25 \pm 0.85^{\mathrm{a}}$ & $3.00 \pm 0.00^{\mathrm{b}}$ \\
Litter weight at & $131.25 \pm 21.98^{\mathrm{ab}}$ & $100.00 \pm 6.36^{\mathrm{ab}}$ & $147.25 \pm 20.99^{\mathrm{a}}$ & $90.00 \pm 0.58^{\mathrm{b}}$ \\
kindling, (g). & $2.00 \pm 0.41$ & $2.25 .48 \pm 0.49$ & $1.75 \pm 0.85$ & $1.25 \pm 0.48$ \\
Litter size at weaning & $1113.75 \pm 222.67$ & $1269.25 \pm 270.313$ & $943.00 \pm 436.80$ & $699.00 \pm 264.83$ \\
Weaning weight, (g). & $560.50 \pm 10.07$ & $567.25 \pm 17.04$ & $418.25 \pm 140.66$ & $421.75 \pm 140.67$ \\
Average weaning & & & & \\
weight, (g/r). & &
\end{tabular}

$\mathrm{a}, \mathrm{b}$ : Means in the same row with different superscripts differ significantly $(\mathrm{P} \leq 0.05)$.

g/ r: Gram/ rabbit.

\section{REFERENCE}

Aduku, A. O., and J. O. Olukosi. 1990. Rabbit production in the Tropics. Abuja, Nigeria. Global Union Publications.

Aggarwal, B. B., K. Anushree and A. C. Bharti. 2003. Anticancer potential of curcumin: Preclinical and Clinical studies, Anticancer Res., 43: 363 - 383.

Asuquo, B. O. 1993. Optimum mash level in a mixed-forage feeding system for growing rabbits. Journal Animal. Production. Res., 13: 99 - 104.

Ayyat, M. S., I. F. Marai and G. H. ElSayiad. 1995. Genetic and non-genetic factors affecting milk production and preweaning litter traits of New Zealand white does under Egyptian conditions. World Rabbit Science, 3: 119 - 124.

Basavaraj, M., V. Nagabhushana and N. Prakash. 2010 .Effect of dietary supplementation of Pulvis Curcuma Longa on the voluntary feed intake, nutrient digestibility and Growth performance of Broiler rabbits under summer stress.Veterinary World, 3 (8): $369-372$.

Beaumont, C., O. Roussot., N. MarissalAvry., P. Prunet and P. Roubertoux .2002. Génétique et adaptation des animauxd'élevage, INRA Prod. Anim., 15 (5) 343 -348.
Bello, K. O., Kareem, S.O., and Jimoh, B. Z. 2015. Sex and frequency of litter change: effect on growth performance, carcass yield and Haematology of rabbits raised on deep litter system. Nigeria Journal of Animal Production.

Berge, A. C. 2017. Gut health is key to reducing antimicrobial use. International pigs tropics, 32(2): 11-13.

Chantry-Darmon, C., Rogel-Gaillard, C., Bertaud, M., Urien, C., Perrocheau M.,

Chardon, P., and Hayes, H. 2003. 133 new gene localizations on the rabbit cytogenetic map, Cytogenet. Genome Res.103 192-201.

Chattopadhyay, I., Biswas, K., Bandyopadhyay, U., and Banerjee, R. K. 2004. Turmeric and curcumin: Biological actions and medicinal applications. Curr. Sci., 87:44-53.

Durrani, F. R., Mohammed, I., Asal, S., Shhail, S. M., Naila, C., and Durrani, Z.

2006. Effect of different levels of feed added turmeric (Curcuma longa) on the performance of broiler chicks. J. Agr. Biol. Sci. 1, 9-11.

Effiong, O.O., and Wogar, G. S. 2007. Litter performance traits of rabbits under mixed feeding regime. Proceeding 32nd Annual Conference of the Nigerian 
rabbit, turmeric, growth, economic, reproductive performance

Society of Animal Production,Calabar March 18-21, pp: 155-158.

Ekpo, J. S., Etuk, I. F., and Solomon, I. P. 2008. Influence of sex on growth and carcass traits of rabbits fed unpeeled cassava tuber meal, peeled cassava tuber meal and cassava peel meal as energy sources. Journal of Agriculture, Forestry and the Social Science. Volume 6 no pp:24-33..

Emadi, M., and Kermanshahi, H. 2007. Effect of turmeric rhizome powder on performance and carcass characteristics of broiler chickens. Int. J. Poultry Science. 5, 1069-1072.

Food and Agriculture Organization (FAO), (1996). For all poor world summits, FAO Rome, pp.64.

Gondret, F., and Bonneau, M. 1998. Mise en place des caracteristiques du muscle chez le lepin et incidence sur la qualite de la viande, INRA Production, Animal. 11 (5) 335-347.

Grashorn, M.A. 2010. Use of phytobiotic in broiler nutrition an alternative to in feed antibiotic ? Journal of Animal Feed Science. 19:338-347.

Gupta, B. P., Rao, V. P., Reddy, C. E., Satyanaray, B., and Reddy, P.P. 1999. Factors influencing pre-weaning body weights in broiler rabbits. Indian Journal of Animal Research, 33(2):115-120.

Harris, J. C., Cottrell, S., Plummer, S., and Lioyd, D. 2001. Antimicrobial properties of garlic (Allium sativum). Applied Microbiology Biotechnology., 57:282-286.

Holder, G.M., Plummer, J. L., and Ryan, A.J. 1978. The metabolism and excretion of curcumin (1-,7-bis-(4-hydroxy-3methoxyphenyl-1-1,6-heptadiene-3,5dione) in the rat. Xenobiotica,8:761-768

Iheukwumere, F.C., and Okoli, I.C. 2002. Preliminary studies on raw Napoleana Imperialis as feed ingredient. 1: Performance and blood chemistry of weaner rabbits. Tropical Animal Production, 5: 100-110.
Iyabode, C. A., Edith, A. O., Daniel, N. T., and Emmanuel, L. S. 2014. Reproductive response of rabbit does to diets containing varying levels of Horseradish (Moringaoleifera) Leaf Meal. Journal of Biology, Agriculture and Healthcare. ISSN 2224-3208(paper) ISSN 2225-093X. VoL.4,No.19.2014.

Iyeghe-Erakpotobor GT., 2009. Performance of rabbits on stylo and groundnut haulms. Nigerian Journal of Animal Production, 36, 2, 288- 296.

Iyeghe-Erakpotobor, G. T., Okunlola, B. O., and Barje, P. P. 2015. Effect of forage type and level, palm oil supplementation and sex on performance of weaner rabbits. Journal of Animal. Production. Res.27:145-156.

Jayaprakasha, G. K., Jagan mohan Rao, L., and Sakariah, K.K. 2005. Chemistry and biological activities of (Curcuma longa). Trends Food Science Technology. 16:533-546.

Jaya, L. P., Ramesh G. B., Gnana, P. M., Ekambaram, B., and Amareswari, $P$. 2009. A study on the performance of fryer rabbits under different systems of rearing. Livestock Research for Rural Development. Volume 21, Article \#118. Retrieved May 5, 2020, from http://www.lrrd.org/lrrd21/8/laxm21118.h tm

Lazzaroni, C., Biagini, D., and Lussiana, C. 2009. Different rearing systems for fattening rabbits: performance and carcass characteristics. Meat Science, 82, 2200-204. Doi:10.1016/j.meatsci.

Lebas, F. 1983. Small-scalerabbit production, feeding and management system. World animal review, 46: 11-17.

Lee, B. M. and Park, K. K. 2003. Beneficial and adverse effects of chemopreventive agents. Mutation Research. 265-270:523-524.

McNitt, J. I. and Lukefahr, S. D. 1989. Effects of breed, parity, day of lactation and number of kits on milk production of 
rabbits. Journal of Animal Science. 68:1505-15012.

Nistor, E., Bampidis, V. A., Păcală, N., Pentea M., Tozer, J., and Prundeanu, H. 2013. Nutrient content of rabbit meat as compared to chicken, beef and pork meat, Journal Animal Production. 3(4): 172-176.

Obinne, J .I. 2002. Effect of different crude protein and digestible energy levels on the growth performance of rabbits in the tropics. Nigerian Journal Animal Production 35(20):210-216.

Odeyinka, S. M., Oyedele, O. J., Adeleke, T. O., and Odedire, J. A. 2008. Reproductive performance of rabbits fed Moringa oleifera as a replacement for centrosema. 9th World Rabbit Congress, June 10-13th, 2008 -Verona - Italy. 7(3)142-147.

Okereke, C. O., Okachukwu S. N., and Okereke, I. H. 2009. Performance of rabbits fed Hausa potato meal at various inclusion 1, Proceedings of the 34th Annual Conference of Nigerian Society for Animal production 15th-18th March, University of Uyo, Akwa Ibom State. pp 140-142.

Oladunjoye, F. O., Adedeji, T. A., and Ojebiyi, O. O. 2006. A guide to Rabbit production and management. Ola printers, Ogbomoso. Pp.3-4.

Omage, J. J., Onimisi, P. A., Adegbite, E. K., and Agunbiade, M. O. 2007. The effect of Ginger (Zingiber officinale Roscoe) waste meal on growth performance, carcasscharacteristics, serum lipid and serum cholesterol profiles of Rabbit. Pakistan Journal of Nutrition 6 (4): 359-362, 2007 ISSN 1680-5194.

Osawa, T. Y., Sugiyama, M., Inayoshi., and Kawakisi, M. 1995. Anti-oxidative activity of tetrahydrocurcuminoids. Biotechnology Biochemistry. 59: 1609161.

Panda, K., Rama Rao, S. V., and Raju, M. V. 2006. Natural growths promoters have potential in feeding systems. Feed Techechnology, 10:23-35.
Panda, K., Rama Rao, S.V and Raju, M. V.2009.Phytobiotic, a natural growth promoter. Poultry. International. Pp.1011.

Petrescu, D. C., Oroian, I. G., Mihaiescu, T., Paulette, L., Varban, D., and Patrutoiu, T. C. 2013. Rabbit statistics overview: production, trade, market evolution. Rabbit Gen 3(1):15-22.

Poigner, J., Szendrộ, Z., Lèvai, A., Radnai. I., and Birớ-Nemeth, E. (2000). Effect of birth weight and litter size at suckling age on reproductive performance in does as adults. World Rabbit Science. 8:103-109.

Ramirez-Tortosa, M.C., Mesa, M.D., Aguilera, M.C., Quiles, J.L., Baro, L., Ramirez-Tortosa, C.L., MartinezVictoria, E. and Gil, A. 1999: Oral administration of a turmeric extract inhibits LDL oxidation and has hypocholesterolemic effects in rabbit's experimental

atherosclerosis.Atherosclerosis, 147:371378.

Salih, N.H. 2013. Effect of turmeric powder on growth performance, carcass traits, meat quality and serum biochemical parameters in broilers. Journal of Advanced Biochemical Research. Vol. 3 No 2. 25-32.

SAS. 2002. SAS/STAT Software: Changes and Enhancements through Release 8.1, SAS Institute Inc., Cary, NC.

Soni. K. B., Lahiri, $M$ and Chakradeo, $P$. 1997. Protective effect of food additives on aflatoxin-induced mutagenicity and hepatocarcinogenicity. Cancer Letters. 115(2): 129-133.

Wuthi-udomler, M., Grisanapan, W., LuanratanaO.andCaichompoo, W. 2000. Anti-fungal activities of plant extracts. South East Asian Journal Tropical Medical Public Health.31, Suppl., 1:178-182 